\title{
Shipwrecks off the Bushehr port in the Persian Gulf
}

\author{
Hossein Tofighian* \\ Institute of Archaeology of Iran, Underwater Archaeology Department, Archaeology Research Centre, Si-e Tir St, Imam Khomeini St, \\ Tehran, Iran
}

\begin{abstract}
According to a report by the Centre for Marine Studies in the Bushehr University of Medical Sciences on the discovery of pottery from the seabed in the coastal waters off the Bushehr port, the submarine archaeological department of the archaeological research institute conducted a month-long study. Underwater archaeological operation was carried out in an area of approximately $700 \mathrm{~m}$ long and $250 \mathrm{~m}$ wide. The area is located $500 \mathrm{~m}$ from the shores of Bushehr port at a water depth of 3 to $6 \mathrm{~m}$. Cultural materials including torpedo shaped crocks and different types of glazed pottery were identified on the seabed.
\end{abstract}

Keywords: Bushehr, Persian Gulf, Sassaniad, stone anchor, torpedo jar.

\section{Introduction}

THE Persian Gulf, as a strategic waterway, has always been a major waterway for the rulers of maritime trading countries on either side of the gulf, especially for the ships sailing from both the east and west, during the last several millennia. In the bed of the Pars Sea, many shipwrecks have been documented and a number of historical sites have been identified ${ }^{1}$. A few shipwrecks have also been reported from the waters of the Iranian Persian Gulf. All discoveries are based on the identification of cargo shipments found in the shallow sea. Deepwater surveys have not so far been conducted. Therefore, surface-mounted measuring devices used for recording submerged historical shipwreck need to be employed $^{2}$.

Underwater archaeological surveys in the shallow seas off the coast of Bushehrport have brought to light a large variety of Sassanid pottery. But the remains of cargo material, wreckage of ships have not so far been found. It is hoped that future surveys using sonar scan and profiler can help identify the buried parts of the ships. Therefore, this article is confined to describing the cargo shipments in the Persian Gulf ${ }^{3}$.

\footnotetext{
*e-mail: htofighian@yahoo.com
}

\section{Area of research}

The city of Bushehr port is at the centre of Bushehr Province in south-western Iran, in the Persian Gulf. The port is located $18 \mathrm{~m}$ above sea level and the region experiences warm semi-arid climate ${ }^{4}$. The city of Bushehr is variously named as Ram Ardashir, Abu Shahr, Bokht Ardashir, Lian and Rishahr in historical records (Figure 1) ${ }^{5}$. The area for detailed underwater survey was identified with the help of Bushehr University of Medical Sciences department researchers. The Bushehr port is a potential region for underwater archaeology. The site is located $500 \mathrm{~m}$ from the coastline of the Bushehr port, between the customs wharf and the Bushehr city council building. This underwater site was first identified by the researchers of marine medical centre affiliated to Bushehr University of Medical Sciences. Surveys so far carried out in the area have brought to light torpedo-shaped jars, small and large vessels, large water and food storage crocks, along with the dispersion of glazed pottery and a stone anchor. These are good clues for locating the shipwreck site. Logistic shortcomings have hindered deepwater surveys and as a result the data is limited to the present collection.

\section{Survey method}

An area of about $700 \mathrm{~m}$ long and $250 \mathrm{~m}$ wide was selected to fix the starting and end points of the survey ${ }^{6}$. The starting point of the survey was recorded on the boat by GPS and the first arrow was fixed at this site. Detailed survey was carried out by following the same method.

We set the beginning and end of the range by two arrow signs. We then searched underwater along the $700 \mathrm{~m}$ route of the rope. Following this, the search was carried out along the $250 \mathrm{~m}$ wide area. The divers examined the seabed in a circular search pattern survey along fixed points with the help of GPS. The use of ropes was essential because of high turbulence in the subsurface waters. Although this approach is outdated, we were compelled to follow this route for the lack of devices such as sonar and profiler devices. The underwater sites were mapped ${ }^{7}$. Turbidity was a great hindrance. Owing to low visibility in the survey area, the Quad copter and sonar scanner were less useful for understanding the 
condition of the beaches and for detecting materials in the seabed.

\section{Shipwreck remains and findings}

Sporadic occurrence of potsherds, some intact pots and apart of stone anchor indicated the presence of a sunken ship near the shores of Bushehr Peninsula. The torpedo shaped pottery, medium-sized crocks with four horizontal handles and a number of medium sized glazed crocks of turquoise colour and a few small vessels were found in the sediment, which suggest that the site can be dated precisely (Figures 2-5). The torpedo-shaped ceramics belong to the Late Parthian to the end of the Sassanid period. During the first two centuries after the Islamic period valuable liquids such as olive oil, fish salt profit, wine and sometimes cereals were transported from the Iranian ports to the destinations along the Arabian coasts of the Persian Gulf, the Indian subcontinent, East Africa and East Asia ${ }^{8}$. The inside of these ceramics was coated with bitumen to waterproof them ${ }^{9}$. The turquoise glazed and green coloured pottery found at the sites is good evidence to establish links with the Arabian, East African, Indian and East Asian trading nations, suggesting the widespread Sassanid commercial network in the Persian Gulf ${ }^{10}$.

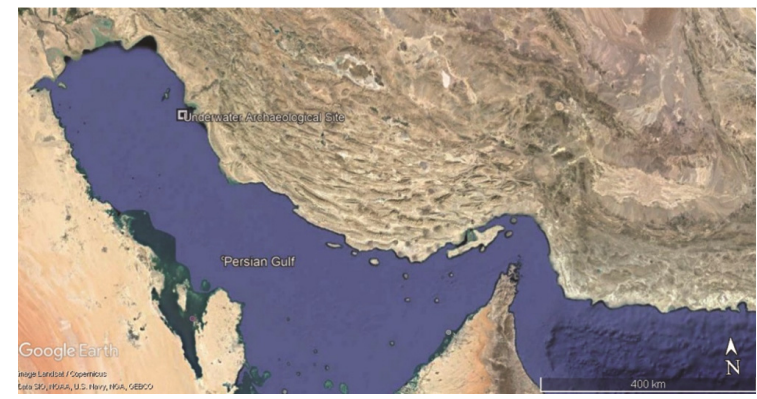

Figure 1. Location of Bushehr port and the underwater site off the Bushehr (Google Earth).

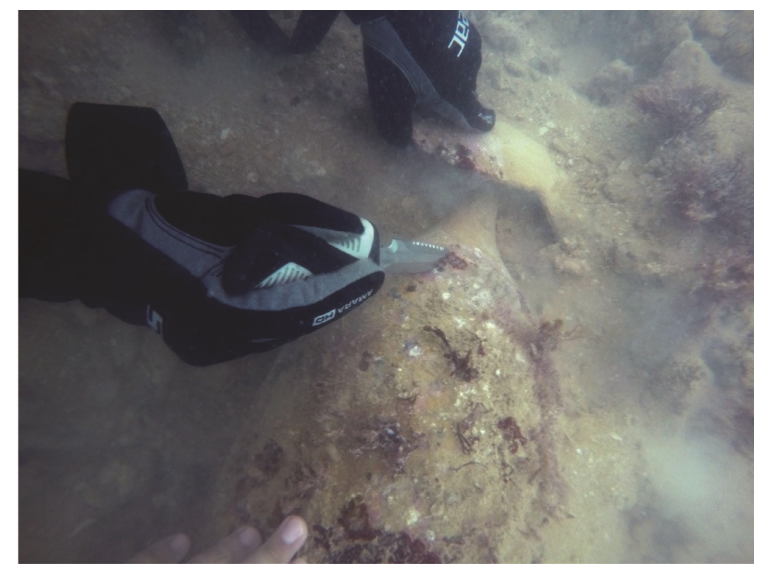

Figure 2. Discovered torpedo shape crock from shallow coasts off the Bushehr port.
One of the most important findings included a composite stone anchor which is oval in shape with three holes on it (Figure 6). Unfortunately, the sunken ship was not traced, but for scattered and heavily damaged cargo remains. Further surveys are essential to ascertain the nature and cause of wreckage.
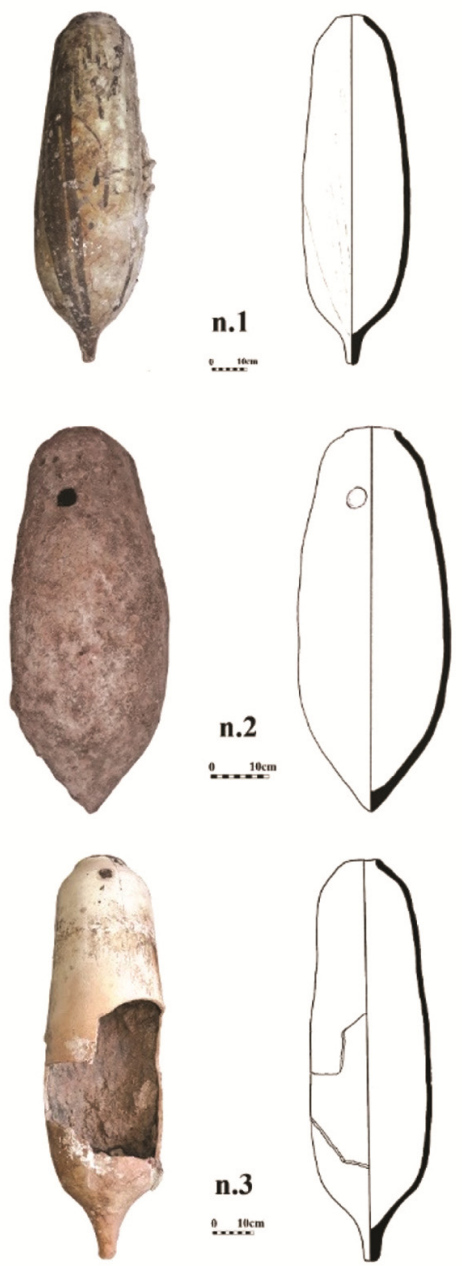

Figure 3. The torpedo-shaped pottery from Bushehr waters.

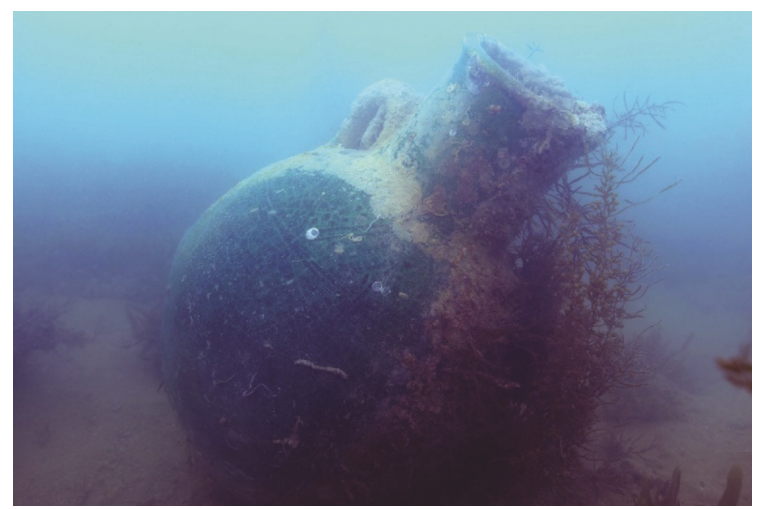

Figure 4. The monochrome glazed jars, the coast off the Bushehr port. 


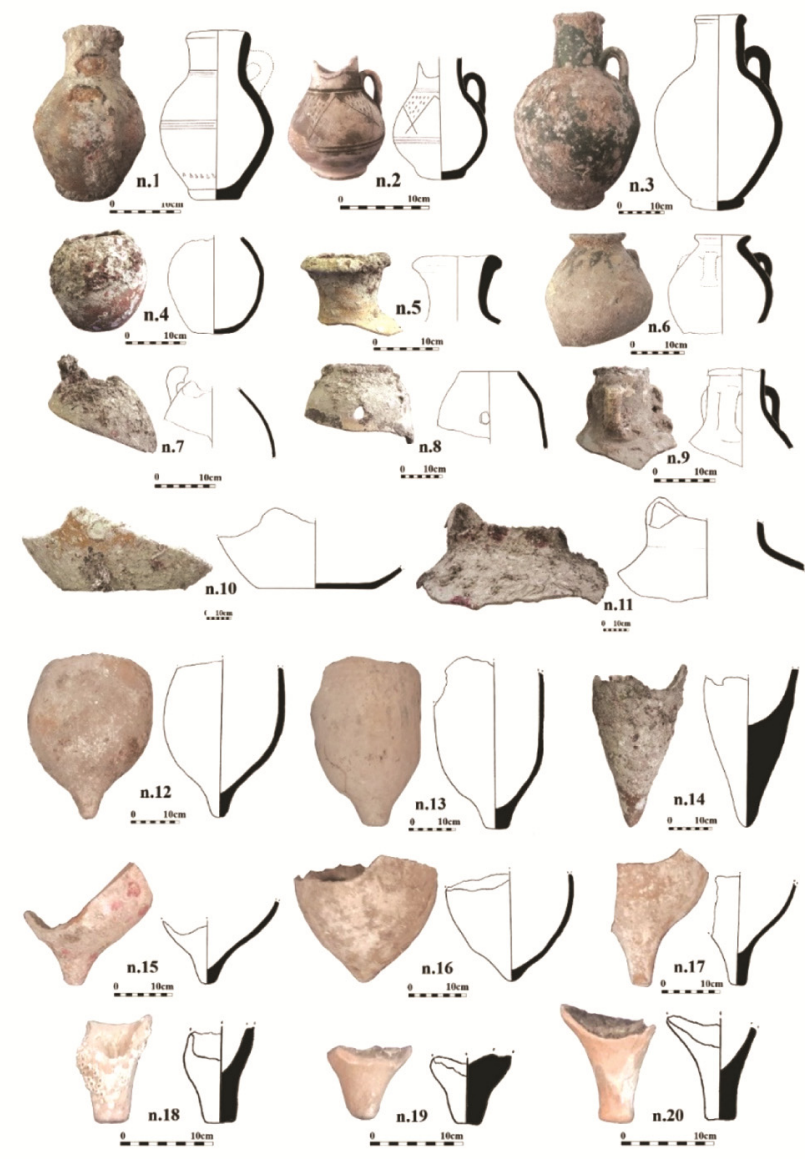

Figure 5. Variety of pottery discovered in the shallow waters off the Bushehr port.

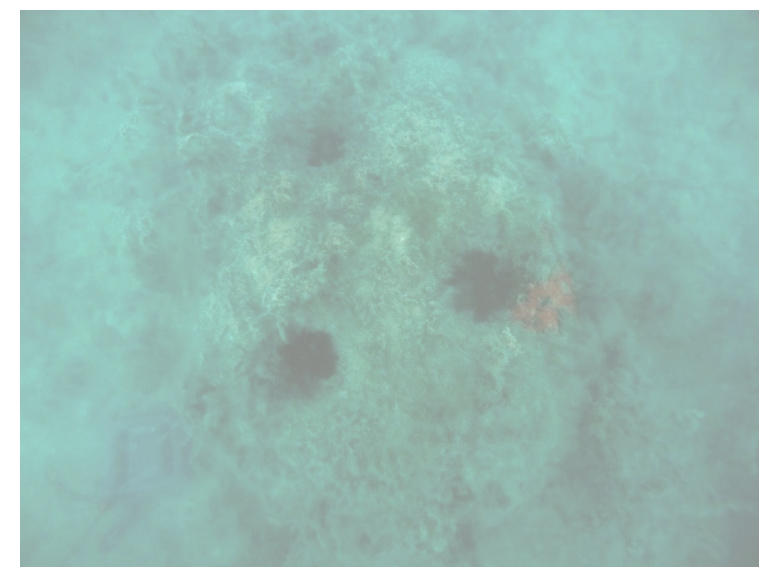

Figure 6. Composite stone anchor from the coasts off the Bushehr port with three holes.

During the Sassanid period, merchant ships transported the Iranian goods, including wines produced in southern Iran to East Africa, India and East Asia. The wine produced in Iran was originally made in the torpedo-shaped pottery with a sharp base and open mouth, that was specially made for this purpose. This was a valuable container used for shipping. Evidence of potsherds of this ware found on the coasts of Arabia, the Persian Gulf, eastern Africa, India and Ceylon and East Asia attests the geographical extent of Iranian wine trade during the Sassanid period $^{11}$.

It should be noted that the torpedo-shaped crocks were also used as a funeral barn during the Sassanian period. Evidence of these burial barns is visible in the Bushehr Shaghab cemetery ${ }^{12}$. Along with torpedo shaped pottery and stone anchor, another typical pottery of the Sassanid period was the turquoise pottery.

\section{Conclusion}

On the shallow seas off the Bushehr port, an ancient site was identified at a water depth of 3 to $6 \mathrm{~m}$. During the surveys, torpedo shaped crocks which were used as wine carrier have been recovered. Intensive underwater search is likely to yield much more material belonging to shipwrecks. Better understanding of this site is essential for determining its true identity as there is enormous scope for further investigations that requires more field studies, which can be planned in the near future.

1. Tofighian, H., Examination and Identification of Northern Ports of the Persian Gulf, Archaeological Exploration Centre, Institute of Archaeology, Tehran, 2010, p. 73.

2. Tofighian, H., Underwater Archaeology in Iran, Samira Publications, Tehran, 2006.

3. Tofighian, H., Underwater archaeology of Bushehr shores. J. Archaeol. Stud., 2019, 19, 23.

4. Afshar Sistani, I., A Look at Bushehr, Tehran Young Generation Publishing and Education Institute, Tehran, 1999.

5. Estakhri, Abu Ishaq Ibrahim Ebn Muhammad Farsi, Masalek and Māmalek (tr. Iraj Afshar), Ministry of Culture and Education, Scientific and Cultural Company, Govt of Iran, Tehran, 1987, pp. 54-76.

6. Fleming, N. and Mark, R. N., The Immersion in the Past, Message of the UNESCO No. 210 (tr. Yousef Majidzadeh), 1988, p. 65.

7. Bowens, A., Underwater Archaeology, The Nas Guide to Principles and Practice, Black Well Publishing, London, 2009.

8. Simpson, St. J., Aspect of the Archaeology of the Sasanian Period in Mesopotamia, Oxford University Press, Oxford, 1992.

9. Connan, J., Evershed, R. P., Biek, L. and Eglinton, G., Use and trade of bitumen in antiquity and prehistory: molecular archaeology reveals secret of past civilisation. Philos. Trans.: Biol. Sci., 1999, 354(1379), 33-50.

10. Mason, R. B. and Keal, E. J., The Abbasid glazed wares of Siraf and Basra connection and petrographic analysis. Iran, 1991, 29, 51-66.

11. Stern, B., Connan, J., Blackelockm, B. and Jackmanm, R., From Susa to Anuradhapura: reconstructing aspects of trade and exchange in bitumen-coated ceramic vessels between Iran and Sri Lanka from the Third to the Ninth centuries AD. Archaeometry, 2008, 50, 409-428.

12. Rahbar, M., Report of Shoghab Cemetery, Documentation Centre of Cultural Heritage and Tourism Organisation of Iran, 2000, p. 42.

ACKNOWLEDGEMENT. I thank my colleagues and others who assisted me in fieldwork and extended support.

doi: $10.18520 / \mathrm{cs} / \mathrm{v} 117 / \mathrm{i} 10 / 1690-1692$ 